\title{
Trial Panels - A Useful Prerequisite for Cut off Wall Execution: Upper Gotvand Dam
}

\author{
A. Zabihollah Zadeh, M. Karbalaei mohammadi, and M. R. Norian
}

\begin{abstract}
Right abutment of Gotvand Dam, the highest rock fill dam of Iran is featured by dislocated materials and anticline. Thus initial sketch of grouting curtain has been replaced by cut off wall to make it sufficiently water tight. Trial panels can illuminate probable practical obstacles for major phases. The purpose of study was to evaluate execution of support reinforced walls, brushing operation, slurry quality, and excavation efficiencies. Assessment of joint and contacts regarding accomplishment method for basement concrete has been another objective. Thus two trial phases were practiced. Then using survey panels, core sampling, and qualitative monitoring of slurry, several beneficial data were elicited. Longitudinal brushing couldn't be performed effectively. Lack of excavating completion surface provides tighter joints in between basement concrete and cut off panels. In order to prevent clay entrance in between panels and support lateral wall, guide wall has to be fabricated in same width as cutter length, otherwise differential has to be implemented as tolerance into inner panels. Observations and other data sources available were resulted in $320 \mathrm{~m}$ long central plastic concrete wall, designed in 12 phases and 128 panels in which primary and secondary panels have $40 \mathrm{~cm}$ overlap with each other.
\end{abstract}

Index Terms-Cut off wall, practical obstacles, panel contacts, trial panels.

\section{INTRODUCTION}

As we know geological and geotechnical findings mostly satisfy needs to design proper water tight system.

Since right abutment of Gotvand dam is consisted of dislocated materials, anticline, and some other problematic features, considerable deformations were expected in cut off wall surroundings. Then, decision was made to check whether if sort of reinforced concrete could be accomplished to support plastic concrete wall or not? On the other hand to impede cut off wall nailing into body mass core, kind of cap structure was proposed. Thus detection of expander material behavior on wall top portion, as well as slurry quality, longitudinal brushing of panels, resistance of layers for excavation, and contacts quality regarding opted method for basement concrete casting were major objectives.

We didn't know what practical hinders might be faced and what support facilities might be required. Thus, we were about to practice trial panels and observe practical results. Survey panels (SW) as well as drilled cores reveal concrete as well as contact qualities. Records during cutting operation

Manuscript received May 20, 2014; revised August 23, 2014. This work is supported in part by Iranian Department of Power under financials of Gotvand Dam construction. We acknowledge their beneficial supports.

The authors are with the Mahab Ghodss Consulting Engineering Company, Iran (e-mail: alizabihollah@yahoo.com). at body zones including GC, Contact Clay, and Rock fill as well as various geological layers enable us to adjust operation schedule, provide sufficient support equipment and making best use of excavating slurry as well.

\section{Methods (Upstream First Phase Trial Panels)}

To assay collapse risk for excavated layers and other mentioned objectives, we were about to start operation in right bank, upstream dam axis at elevation of about $150 \mathrm{~m}$, the

Layers similar to right abutment disturbed zone. An excavating machine named $\mathrm{BC} 30$ produced by BAUER Corporation was chosen to accomplish experimental panels PT1, PT2 with 80 meters depth.

\section{A. Excavation Rate}

Excavation efficiencies, elicited of mentioned operation are briefly outlined here in Table I.

Operation in PT2 reveals that highly weathered, coarse conglomerate with poor matrix was excavated in 4.9 $(\mathrm{cm} / \mathrm{min})$, however $\mathrm{BC} 30$ can dig fine conglomerate with sand stone and calcite cement matrix in 4.1 and sand stone in rate of $4(\mathrm{~cm} / \mathrm{min})$. It is noticeable that for frequent layers of silt and mud stone it runs in 4.5 to $7.5(\mathrm{~cm} / \mathrm{min})$ pending on its share of clay, silt, and sand stone minerals.

\begin{tabular}{|c|c|c|c|c|c|c|}
\hline $\begin{array}{l}\text { Panel } \\
\text { Name }\end{array}$ & $\begin{array}{c}\text { Cutting } \\
\text { Dimen } \\
\text { sion } \\
(\mathrm{m} \times \mathrm{m})\end{array}$ & $\begin{array}{c}\text { Operation } \\
\text { Elevation } \\
\quad(\mathrm{m})\end{array}$ & $\begin{array}{l}\text { Cutting } \\
\text { Time } \\
\text { (H:M) }\end{array}$ & $\begin{array}{l}\text { Cutting } \\
\text { Volume } \\
\text { (m3) }\end{array}$ & $\begin{array}{c}\text { Cutting } \\
\text { Depth } \\
\text { (m) }\end{array}$ & $\begin{array}{c}\text { Cutting } \\
\text { Efficie } \\
\text { ncy } \\
(\mathrm{m} / \mathrm{H})\end{array}$ \\
\hline PT2 & $2.8 \times 0.8$ & 150 & $24: 10$ & 168 & 75 & 3 \\
\hline PT1 & $2.8 \times 0.8$ & 150 & $10: 05$ & $\begin{array}{c}119 . \\
84\end{array}$ & 53.5 & 5 \\
\hline
\end{tabular}

Whereas PT1 was cut at rate of about $8.7 \mathrm{~m} / \mathrm{H}$ (meter per hour) for high permeable coarse conglomerate in rock fill zone from 20 to $36 \mathrm{~m}$ depth. Fine conglomerate from about 20 to $29 \mathrm{~m}$ with calcite cementation was excavated in 6.2 $\mathrm{m} / \mathrm{H}$. Low fine content sand stone shows $6.0 \mathrm{~m} / \mathrm{H}$ from 29 to 35 , and silt stone involved mud stone demonstrates $3.75 \mathrm{~m} / \mathrm{H}$ in 35 to $49 \mathrm{~m}$ depth. Finally 49 to $53.5 \mathrm{~m}$ is consisted of sand stone grading conglomerate that excavated in 4.5 meters per hour.

\section{B. Cutter Bit Demolition}

PT2 excavation has totally consumed 42 bits; the layers in which more bits were damaged are well cemented fine conglomerate. Most cutter wheel blades were changed during first panel excavation, and then only 2 blades were changed for PT1 cutting operation in calcite matrix conglomerate. It is apparent any changes in cutter size and weight influences 
transferred normal force to bed rock through bits, and then affect excavation efficiencies (see Fig. 1) Bits' type influences operation as well (see Fig. 2) [1].

It is notable that ordinary bits ( $\mathrm{Sb}$ ) is used to cut formations with uniaxial compressive strength up to $50 \mathrm{MPa}$, whereas rock bits (RSC) and Roller bits are applied to excavate stones with compressive strength of about (50-100) and upper 100 MPa respectively.

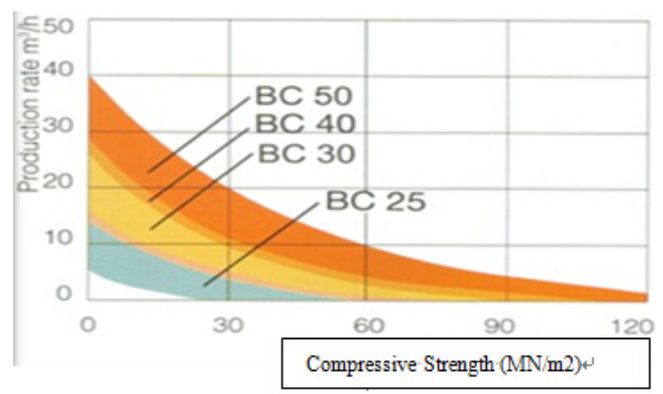

Fig. 1. Production rate, cutter size effect.

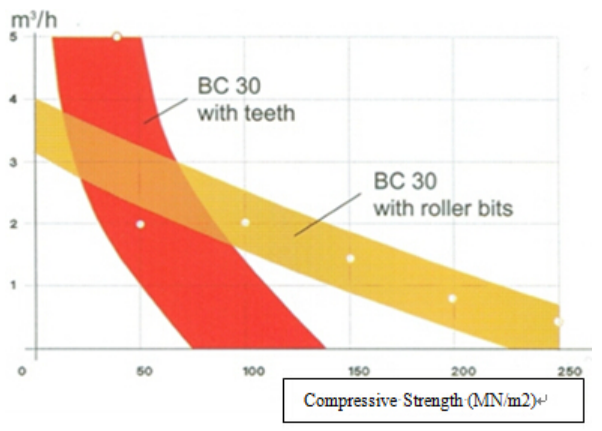

Fig. 2. Production rate, cutter bit effect.

We've taken advantage of mentioned blades during trial panel cutting operation in Fig. 3.
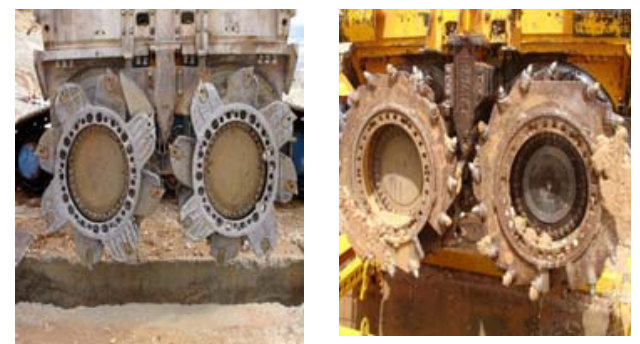

Fig. 3. Cutter wheel, Sb blades (a), RSC bits (b).

\section{Slurry Leakage}

Monitoring during excavation and concrete placement of PT2 reveals no collapse; however slurry was leaked two times during cutting operation. Firstly leaked in GC materials of body mass core under gravel and secondly through two formations contact, sandy gravel conglomerate and sandy clayey siltstone. Leakage was observed in $38 \mathrm{~m}$ depth and occurs at rate of $12(\mathrm{~cm} / \mathrm{min})$, which was treated by $3 \mathrm{~m}^{3} \mathrm{GC}$ materials. However no slurry escape was observed during PT1 excavation. It seems nearly $20 \mathrm{~m}^{3}$ escaped mud of first panel, made any probable open voids available in PT1 surroundings filled.

\section{Upstream Second Phase Trial PANELS}

To simulate accomplishment of cut off wall phases, we were about to devise experimental panels in minimum excavation and subsequently concrete placement sketch to increase operation speed and decrease cost as well.

\section{A. Excavation Survey}

Devised panels were grouped as $P$ panels, lateral right panels RT, lateral left panels LT, and survey panels SW in Fig. 4.

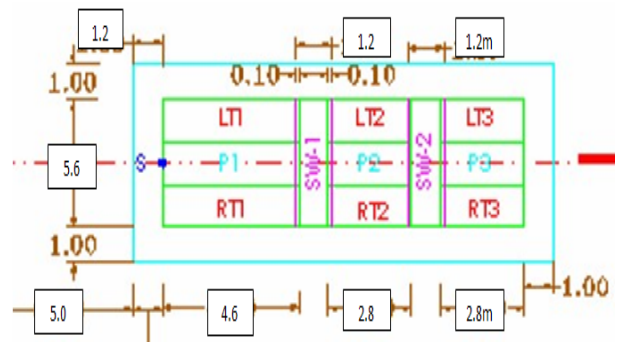

Fig. 4. Experimental panels' sketch plan.

In lateral and survey panel operations, $177.7 \mathrm{~m}$ depth in an area of about $392.1 \mathrm{~m}^{2}$ was dug out by BC 40 in Fig. 5 .

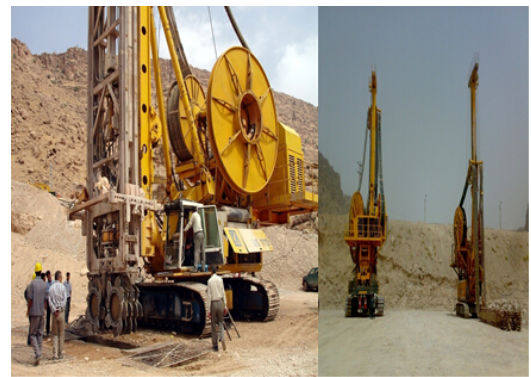

Fig. 5. BC 30 sets on PT2 platform (a), used BC30, BC40 (b).

Average cutting speed for various layers are registered in Table II.

\section{B. Slurry Qualitative Survey}

Slurry dirt depends on both excavated material and mud fluid absorption attributes. Available materials are highly pollutant and concrete cutting exacerbates pollution appreciably [2]. Cement is alkaline and its ionic exchanges make excavating slurry much more consistent. In experimental platform, pollution of fresh slurry in clay and concrete layers were monitored in Table III.

\section{Brushing}

Although brushing job is commonly performed in secondary panels' width, in order to evaluate cleaning of basement concrete surface that will be in contact with primary and secondary plastic concrete walls, brushing was tested along cutter as well.

\section{Reinforced Lateral Walls}

As we mentioned before, weak geotechnical situation of right abutment will cause remarkable forces on plastic concrete cut off wall because of recent and prospective settlement and movements. In order to be protected, two lateral reinforced walls were proposed all along cut off wall in both sides. Thus three panels, RT1, RT3, and LT1 were chosen to examine operation and foresee probable obstacles for major phases in Fig. 6. 
TABLE II: AVERAge CUTTING SPEEd For DifFERENT LAYERS (BC40)

\begin{tabular}{|c|c|c|c|c|c|c|c|}
\hline $\begin{array}{c}\text { Layer } \\
\text { Genus }\end{array}$ & GC (Gravely Clay) & $\begin{array}{c}\text { Filling } \\
\text { Concrete }\end{array}$ & Basement Con. & $\begin{array}{c}\text { Rock } \\
\text { Fill }\end{array}$ & Conglomerate & $\begin{array}{c}\text { Mud } \\
\text { Stone }\end{array}$ & $\begin{array}{c}\text { Sand } \\
\text { Stone }\end{array}$ \\
\hline $\begin{array}{c}\text { Exca. Volume } \\
\text { (m3) }\end{array}$ & 234.26 & 83.16 & 18.5 & 90.5 & 177.4 & 85.6 & 18 \\
\hline $\begin{array}{c}\text { Exca. Rate } \\
\text { (cm/Min) }\end{array}$ & 32 & 24 & 13 & 22 & 4.5 & 6.1 & 4 \\
\hline
\end{tabular}

TABLE III: QUALITATIVE SLURRY MONITORING FOR INITIAL PANELS

\begin{tabular}{|c|c|c|c|c|c|c|c|}
\hline Used Slurry & $\begin{array}{c}\text { Layer } \\
\text { Genre }\end{array}$ & $\begin{array}{c}\text { Density } \\
(\mathrm{gr} / \mathrm{cm} 3)\end{array}$ & $\begin{array}{c}\text { Marsh } \\
(\mathrm{sec} .)\end{array}$ & $\begin{array}{c}\text { Percentage } \\
(\%)\end{array}$ & PH & $\begin{array}{c}\text { Cake Thickness } \\
(\mathrm{mm})\end{array}$ & $\begin{array}{c}\text { Filtered Water } \\
(\mathrm{ml})\end{array}$ \\
\hline Fresh Slurry & --- & 1.03 & 29 & --- & 7 & 1.5 & 30 \\
\hline $\begin{array}{c}\text { Recycled Of } \\
\text { Clay }\end{array}$ & Clay & 1.08 & 37 & 0.5 & 8 & 10 & 30 \\
\hline $\begin{array}{c}\text { Recycled Of } \\
\text { Clay }\end{array}$ & Concrete & 1.09 & 38 & 3.5 & 11 & 11 & \\
\hline $\begin{array}{c}\text { Recycled Of } \\
\text { Concrete }\end{array}$ & $\begin{array}{c}\text { Rock } \\
\text { Fill }\end{array}$ & 1.17 & --- & 3.5 & 11 & $>50$ \\
\hline
\end{tabular}

Bar cage has $20 \mathrm{~cm}$ concrete cover in width as the interface with couple adjacent panels and $10 \mathrm{~cm}$ in length.

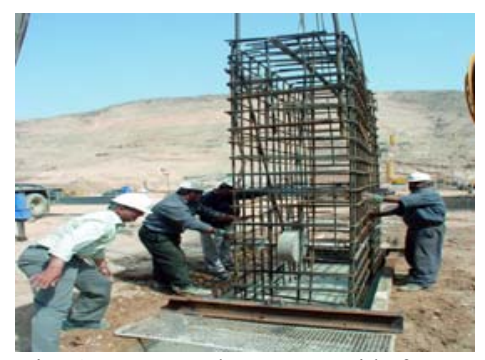

Fig. 6. Bar cage placement, guide frame.

A guide frame with two guide plates, installed on each side was applied to direct bar cage into panel. To direct cage more accurately and to fix it specifically during concrete placement 4 roller shaped concrete pieces have been applied.

Of course concrete covers were contemplated as well. Cage was hanged in 0.3 to $0.6 \mathrm{~m}$ of panel bottom and $1.3 \mathrm{~m}$ of guide wall surface at top for RT1 and PT1 panels. To simulate lateral walls in actual cut off wall axis more accurately, top space of about $3 \mathrm{~m}$ was considered for RT3.

To facilitate concrete placement sort of opening was devised into reinforcement cage for tremie pipe to pass through.

\section{E. Concrete Placement}

By taking advantage of saturated bentonite slurry, a plastic concrete mix design named PC15 was used for principle panels, P1, P2, and P3 [3]. Total geometric volume for three panels has been $183.6 \mathrm{~m}^{3}$ and concrete placement takes about 2:06 hours for P1 and 1:50 hours for P2 and P3 regarding their similar dimensions. Necessity of concrete placement through tremie pipe made us to employ kind of high performance structural mix named T165 with $19 \mathrm{~cm}$ slump for lateral walls [4]. In order to check expanders' effect on probable cake thickness in beneath or lateral joints as well as its plausible effect on concrete volume and performance, Cebex 100 was applied in $0.55 \%$ of cement weight in concrete mix design.

\section{SURVEY PANELS}

To survey fulfillment results of principle and lateral trial panels, SW1 and SW2 were dug.

SW1 was excavated to $7.3 \mathrm{~m}$ deep in $3.6 \mathrm{~m}$ length and continued by $2.8 \mathrm{~m}$ length to $12.5 \mathrm{~m}$ deep. This section change was occurred because of two reasons. Collision to lower part of RT1's cage. Besides high vibration made of cutting operation in $30 \mathrm{MPa}$ basement concrete specifically when cutter isn't confined in $2.8 \mathrm{~m}$ precut side and cutter wheel flaps couldn't be applied efficiently. When SW2 get started, installed cage in RT3 moved upward and diverted into SW2 cutting path. Thus operation was continued in between LT2, P2, LT3, and P3 in standard cutter length $2.8 \mathrm{~m}$ with no corrupting cages, deep to $10.2 \mathrm{~m}$. Finally to make precise observation possible an access trench was cut, deep to basement concrete surface (see Fig. 7).

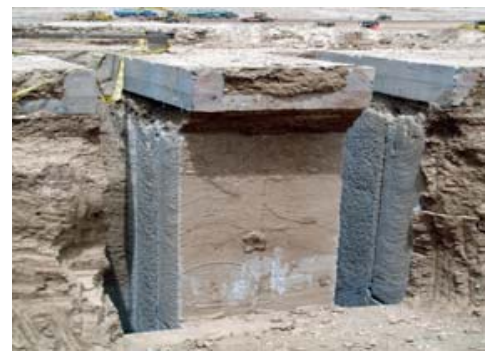

Fig. 7. Observation trench.

\section{CORE SAMPLING}

To check casted in concrete as well as contact qualities some cores were drilled. For L and R panels some $76 \mathrm{~mm}$ cores were drilled in center of each one, deep to 9 and 10.4 meters respectively.

In LT2 a uniform core with no crack was elicited of 6 to 9 $\mathrm{m}$. Contact of central and lateral panels was expected at $7.5 \mathrm{~m}$. Another sample core was evoked of 1.3 to $9 \mathrm{~m}$ depths at LT2 and a $0.1 \mathrm{~m}$ length fracture was revealed at 7.4 to $7.5 \mathrm{~m}$ depth. Contact depth was confined in 7.1 to 7.5 and concrete pollution was observed in 7.2 to $7.5 \mathrm{~m}$ depth as well. It is noticeable that outcome of Lojun test at pressure of about 6 bars has been zero [5]. No cracks were detected in LT3 drilled core from about 1.85 to $9 \mathrm{~m}$. However it was polluted in some points by bentonite slurry and was fractured during drilling operation. Concrete contact with lateral was detected in $7.5 \mathrm{~m}$ depth. 
RT1's core had $0.1 \mathrm{~m}$ fractured parts at 7 to $10 \mathrm{~m}$ depth. Concrete and lateral contact was recognized in $9 \mathrm{~m}$ and some cracks were visible along core as well. Core elicited of RT2 illustrates no crack from about 7.7 to 10.4 and Lojun result has been zero in panel deep. Core depth of RT3 shows no break at 7 to $10 \mathrm{~m}$ and concrete contact with lateral was clear at 9 meters.

\section{CONCLUSIONS}

Geological and geotechnical studies illuminate that grouting curtain is unable to seal right abutment because of its unstable features. Thus based on this recognition besides trial panel results as well as surveys of similar experience at Karkheh dam [6], 302m long cut off wall was designed in 12 phases and 128 panels with average depth of about $107 \mathrm{~m}$.

1) Regarding trench cutter size effect on excavation power, $\mathrm{BC} 30,40$, and 50 were assigned for various cut off phases respectively, in which more stiff layers like conglomerate, sand stone, and mud stone were exist. Proportionate support facilities such as enough cutter bits have to be provided as well.

2) Measured cutting efficiencies for different genres parallel to geological recognition of site, enable us to present an actual schedule program for cut off wall execution.

3) Qualitative evaluation of slurry, made us aware of how much pollutant is each body mass zone or geological genre. This predetermined information besides excavation current controls can specify numbers of appropriate slurry recycles for each state and some other beneficial data as well.

4) Despite considerations implemented, installed brush couldn't satisfy longitudinal brushing expectations and could cover mere $174 \mathrm{~cm}$ of $280 \mathrm{~cm}$ cutter length. When cutter returns to the surface, brush becomes rather teased and polluted by excavating slurry cake as well.

5) Reinforcement cage has to be designed and assembled with arranged pins so that tremie pipe can easily pass through and ball could return from bottom to the surface as well.

6) Cage has to be fixed in an appropriate space of bottom. Seating on panel bottom makes cage polluted with dirty mud. In contrast cage might move during concrete placement, if too space was available in between.

7) Guide frame has to be tightly connected to panel surface guide wall. Guide plates have to be extended deep enough to direct cage more accurately as well.

8) Existing joints between basement concrete and P3 as well as LT3 panels were much better and tighter, in which excavating completion surface was not ensured for basement root.

9) Remains of executed contact clay (pertaining to dam body mass core) were observed in vertical joints between plastic concrete and L lateral panels. Thus 1.25 $\mathrm{m}$, guide wall width has to be diminished to $1.20 \mathrm{~m}$, identical to cutter length or $5 \mathrm{~cm}$ tolerance has to be implemented on inner panels. That way cutter tolerance wouldn't cause materials to remain in joints.

10) In spite of our expectation, bentinite cake was not observed on contact clay during trench cutting operation for lateral panels and just a thin film of bentonite was detected.

11) At vertical joints between $P$ plastic panels and rock fill wall, below basement concrete elevation, minimum cake thickness was revealed. Miniature surrounding pores, collapsed during rock fill operation had been filled by excavation slurry. Conversely collapses in rock fill wall that occur in uniform slopes, had been filled by plastic concrete.

12) As a partial conclusion, central plastic concrete wall was designed in primary and secondary panels so that secondary has to be cut with $40 \mathrm{~cm}$ overlap by primary panel at each side.

13) By taking advantage of mentioned observations, elicited of survey panels and core samplings, cut off wall initial sketch has been adjusted subsequently.

\section{ACKNOWLEDGMENT}

Authors wish to thank technical collaboration of Mr. Azad manesh. Endeavours of Mr. S. Lahijani as project manager are so much appreciated as well. Also, first author thanks Mr. Al-e kasir for his helps in computer job.

\section{REFERENCES}

[1] W. Gang and G. Brunner, "Cut off wall techniques," OSTRE/CONRAD in Proc. the Oil Sands Tailings Conference, vol. 3, Edmonton, Bauer, 2008.

[2] S. O' Brion, C. Dann, G. Hunter, and M. Schwermer, "Construction of the plastic concrete cut off wall at hinze dam," ANCOLD Proceedings of Technical Groups, pp. 1-9, 2005.

[3] V. Bhardwaj, R. Halim, and A. D. Mcandrew, "Design and construction challenges for the plastic concrete cut off wall at the proposed conawapa generating situation in northern manitoba," in Proc. the Canadian Dam Association Conference, Winnipeg, pp. 54-65, 2008.

[4] P. D. Amos, D. A. Bruce, M. Lucchi, T. Newson, and N. Wharmby, Design and construction of Seepage Cut off Walls Under a Concrete Dam in New Zealand with a Full Reservoir, 2007.

[5] P. E. Banzhaf and E. Colmorgen," Reliable seepage control by plastic concrete cut off walls," in Proc. the 31Annual USSD Conference, San Diego, California, vol. 3, 2011.

[6] A. A. Mirghasemi, M. Pakzad, and B. Shadravan, "The world's largest cut off wall at karkheh dam," Hydropower and Dams, no. 2, 2005.

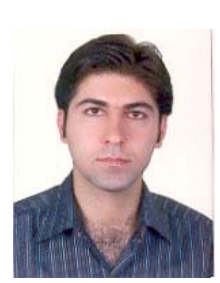

Ali Zabihollah Zadeh was born in Dezful, Iran in 1978 and he earned BSc. degree in irrigation from Shahid Chamran University of Ahwaz, Iran at 2001 as first ranked graduate. He received the MSc. degree in irrigation-hydraulic structures at Shahid Chamran University with major studies on vortex flow hydraulicsat 2004.

$\mathrm{He}$ has been engaged as an instructor of Civil Department of Jundi Shapour University and Azad Universities in the area as well for three years. Statics, strength of materials, soil mechanics, elementary structural analysis, hydrometry, hydrology and geohydrology, surveying, construction materials and methods have been materials, instructed by first author. He cooperated with Karoon Agro-Industerial Company to monitor hydraulic structures available for six months, and he has been hired by Mahab Ghoddss Consulting Engineering Company till now. He acts as the Q.C. inspecting vice president in Upper Gotvand Dam and the head inspector of embankment at one of dam affiliated projects as well. 